\title{
Interpreting the impact of flood forecasts by combining policy analysis studies and flood defence
}

\author{
Robert Slomp ${ }^{1, a}$, Bas Kolen ${ }^{2}$, Hilde Westera ${ }^{1}$, Jaap Verweij ${ }^{1}$, and Durk Riedstra ${ }^{1}$ \\ ${ }^{1}$ Rijkswaterstaat, Ministry of Infrastructure and the Environment, PObox 22323500 GE Utrecht, the Netherlands \\ ${ }^{2}$ HKV Lijn in Water, Botter 1129, 8232 JN Lelystad, The Netherlands
}

\begin{abstract}
Flood forecasting is necessary to save lives and reduce damages. Reducing damages is important to save livelihoods and to reduce the recovery time. Flood alerts should contain expected time of the event, location and extent of the event. A flood alert is not only one message but part of a rehearsed flow of information using multiple canals. First people have to accept the fact that there might be a threat and what the threat is about. People need a reference to understand the situation and be aware of possible measures they can take to assure their own safety and reduce damages. Information to the general public has to be consistent with the information used by emergency services and has to be very clear about consequences and context of possible measures (as shelter in place or preventive evacuation). Emergency services should monitor how the public is responding to adapt their communication en operation during a crisis. Flood warnings and emergency services are often coordinated by different government organisations. This is an extra handicap for having consistent information out on time for people to use. In an information based society, where everyone has twitter, email and a camera, public organisations may have to trust the public more and send out the correct information as it comes in. In the Netherlands Rijkswaterstaat, the National Water Authority and the National Public Works Department, is responsible for or involved in forecasting in case of floods, policy studies on flood risk, policy studies on maintenance, assessment and design of flood defences, elaborating rules and regulations for flood defences, advice on crisis management to the national government and for maintaining the main infrastructure in the Netherlands (high ways and water ways). The Water Management Center in the Netherlands (WMCN) has developed a number of models to provide flood forecasts. WMCN is run for and by all managers of flood defences and is hosted by Rijkswaterstaat. Other organisations use these forecasts to define the consequences of the forecast, to take measures (as the evacuation of camping places on rivers banks or lake shores) or to estimate the conditional probability of failure of a flood defence. Increasing the resilience of the population by disseminating information from both policy studies (flood scenarios) and flood forecasts has been the project goal of the MEGO project "Module Evacuatie Grote Overstromingen", an information tool for large scale evacuation due to floods. This information is available on a national website. The MEGO project has focussed on making the information from two major policy studies on flood risk available, the first sturdy determined new risk-based standards for flood defences (WV21). The second study determined the current flood risk (VNK-2). The MEGO database contains a selection of verified flood scenario's. For each scenario the hydraulic loads which will cause a flood are known as are the probabilities of flooding and predicted casualties and damages. Overland flow maps are available. MEGO combines this data with the flood forecast, open data of the "Cadastre" (national Registry), the national digital terrain model (AHN) and the main infrastructure (local, regional and national). The site offers prepared and real time maps for professionals during a crisis, and tools to increase risk awareness for citizens. The software was recently renamed national water and flood information system, "Landelijk Informatiesysteem Water en Overstromingen (LIWO) " when it went live in 2016. In LIWO the second goal of MEGO was realized, by adding the information from flood forecasts. It is an open source model.
\end{abstract}

\footnotetext{
${ }^{a}$ Corresponding author: Robert.slomp@,rws.nl
} 


\section{Floods low probability and high consequences}

According to the National Risk Assessment by the ministry of Interior in the Netherland [BZK, 2008], floods in the western part of the Netherlands have been identified as a national risk. They are a low probability and high consequences events . 2008 was the first National Risk analysis carried out in a consistent fashion by a multidisciplinary team. This information was not new. The national policy has been focused on the improvement of flood defences since 1961 [Delta Committee, 1961]. This policy is based on a cost benefit analysis [van Dantzig, D. 1956]. The Netherlands consists of a highly urbanized and densely populated country. Major flood are disruptive and a national threat. About $59 \%$ of the country is flood prone. The current national flood risk policy is covered in detail in [Slomp, 2012] and flood policy changes are covered in [Slomp, 2016] and summarized in [Slomp et al, 2016]. The population is not really aware because there has not been a flood since 1953. Awareness should be improved [OECD, 2014].

\section{Flood forecasting in the Netherlands}

\subsection{Interpretation of forecasts}

Interpreting data from flood forecasts can be cumbersome. There are $3600 \mathrm{~km}$ of flood defences in the Netherlands. To simplify the production process and understanding flood alerts the focus has been on water levels at river gauging stations or at tidal gauging stations.

The most basic information to get out to the public on time there is information a storm or river discharge which can cause major damages and/or casualties. In 1953 this information most often did not arrive.

\subsection{Hazard maps}

Since the year 1800 information at gauging stations along rivers and the sea was often the only information available. The statistical information of gauging stations and past floods were used to determine if a hazard was a major risk. By combining information from a "rough" digital terrain model (based on levelling) and statistical information the main 53 flood prone areas were identified in 1996 [VenW, 1996] (see figure 1). In essence this is done by interpolating the statistical information (mathematically or through hydrodynamic models) and combining this digitally with a digital terrain model. This is a digital "putty knife method". No sophisticated overland flow model was used. From 1996-2003 using laser altimetry a new open source digital terrain model has been built Algemeen Hoogte Bestand Nederland (AHN), with 1 point every $16 \mathrm{~m}^{2}$ or 1 point per $\mathrm{m}^{2}$. This was not precise enough for water management purposes [van der Zon, 2013]. After 2003 this was extended to 16 points per $\mathrm{m} 2$ in the AHN2 project. Currently the AHN-3 has been built with .25 points per $\mathrm{m}^{2}$. This has not been publicly disseminated.

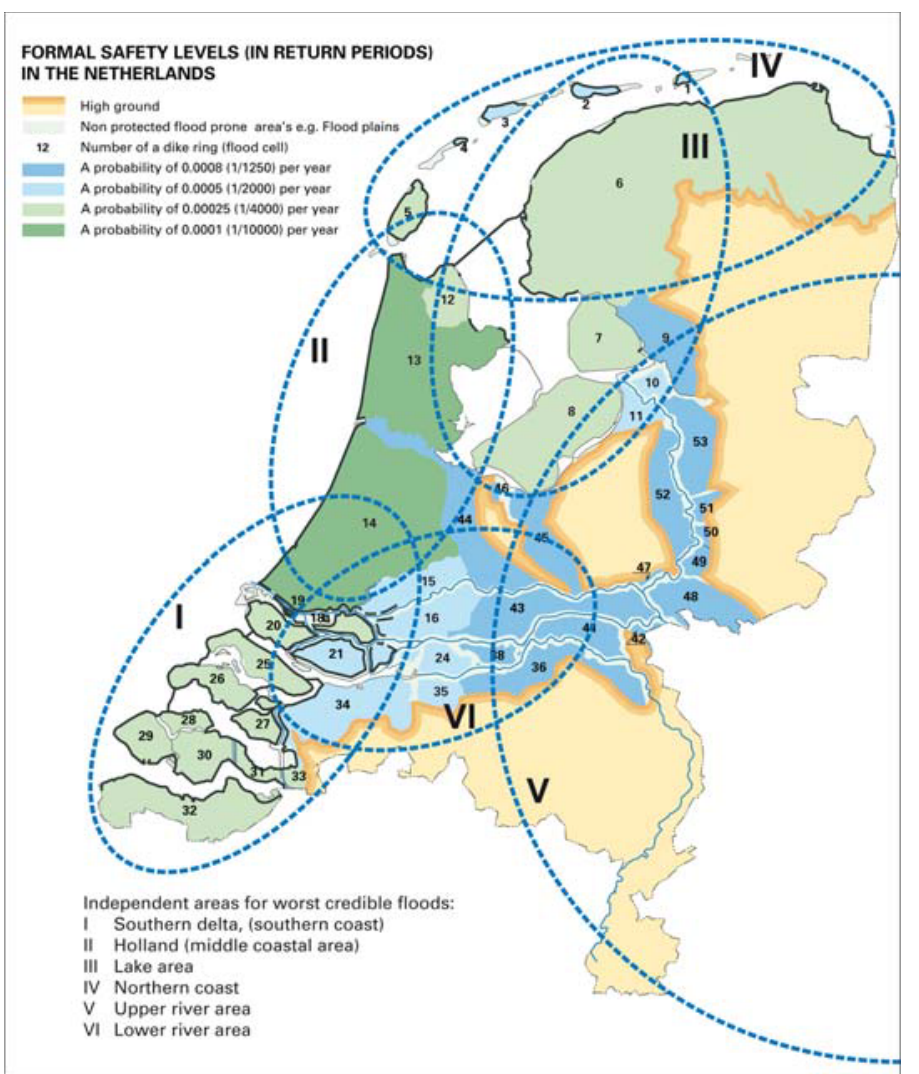

Figure 1. Formal risk based safety standards for flood defences 1996-2017 and the concept of "worst credible floods"[Kolen and Geerts, 2006]

Legend:

Zone 1 Storm ( $>=$ Beaufort 12, $>64$ knots) in Zeeland en the South of Holland

Zone 2 Storm ( $>=$ Beaufort 12, $>64$ knots) the coast of Holland

Zone 3 Storm (> Beaufort 10 or 11) in het Ijssel lake area, estuaries of the Vecht and IJssel

Zone 4 Storm ( $>$ Beaufort 12, $>64$ knots) in the Wadden sea area

Zone 5 Discharge (discharge $>4000 \mathrm{~m} 3 / \mathrm{s}$ Meuse and $>16000 \mathrm{~m} 3 / \mathrm{s}$ Rhine river) en storm (>Beaufort 6, 48-55 knots, to Beaufort 7, 28 to 33 knots) on the major rivers Rhine and Meuse

Zone 6 Intermediate areas, river floods and storm surges together provide the maximum flood event (Beaufort 8 to 11)

For rivers the focus for flood alerts was on water levels at reference points, the river gauges on the border at main cities and in neighbouring countries (e.g Cologne for the Rhine river). In the 1990's statistical methods were used in forecasting using a relationship between upstream and downstream river gauges [Warmerdam, 1986] and [Torfs, 1990]. At river gauging stations on the border the relationship between water levels and the river discharges was determined. This relationship was used to calibrate models which are used to determine the water levels along the river. For flood forecasting for rivers SOBEK is used [Deltares, 2016].

In 1995 during the last high river discharges no information was available on water levels in polders after a breach. 250000 people were evacuated. Some cities built on slightly higher ground which would not flood were never the less evacuated. Evacuation is costly, it disrupts society. This is why the HIS, Information System for High Water, "Hoog Water Informatie Systeem" project was launched. This project had a number of goals: 
1. disseminating information on flood forecasts water levels together with reference information on dike heights.

2. a database with flood scenario's for each province of the Netherlands calculated using a overland flow model, FLS model [Duinmeijer, 2002]

3. a method to calculate the number of casualties and the potential damages [Kok et al, 2005]

4. a set of models to calculate evacuation rates per area [Doef van der, et al, 2004]

Since 1985 forecasting for floods and storm surges in lake areas was carried out. Forecasts were given in run up heights for dike sections along the Lake Ijssel and Lake Marken and the 3 rivers deltas Ijssel, Vecht and Eem. From 1985 until 2007 a database was used. It was built with a large number of storms using WAQUA [Rijkswaterstaat, 2012] and HISWA [Booij et al, 1985] model (a precursor of the SWAN model [Zijlema, 2007].

In 2008 the worst credible flood concept was introduced. Which still plausible scenarios can still be expected. These scenarios per region have been given in figure 1. It is important to note that they are often mutually exclusive. A major 1/100 000 year event on the coast and rivers at the same time is not possible. A $1 / 10$ 000 year event for estuaries is often the combination of events we have already observed in the past. Also a major storm cannot be simultaneously threaten the south western and northern coast at the same time. A depression above Southern Norway threatens our Northern Coast. A depression above our Wadden Sea threatens out south western coast. This is an important notion for contingency planning.

\subsection{Real time forecasting}

The Netherlands has moved from forecasting based on statistical information (only possible for short lead times) to forecasting based on databases filled with scenarios of storms and or discharge, to real time forecasting models.

Currently a real time flood forecasting model is used for each water system.

There is a 10 day forecast for precipitation, temperature and wind speeds and direction from the National Meteorological office, KNMI. However it remains difficult to determine the exact path of a depression with a 2 day lead time.

- A SOBEK model is used for main rivers. Precipitation and discharge data from Germany, Belgium and France is used as input in the models.

- For the coast both tides and storm surges have to be considered together, a Hydro-Dynamic WAQUA model is used which starts at Portugal, Norway and Iceland.

- WAQUA and SWAN are used for the lake regions

Since 2007 the Netherlands has merged flood forecasting centres at the national flood forecasting centre WMCN, managed by the National Water Authority Rijkswaterstaat. There are three main flood forecasting units for the sea coast rivers, rivers and lakes. The focus for flood forecasts is still on water levels, since this is less complex than adding wave action. Only the Lake region provides formal real time wave forecasts in combination with water levels. The main water systems in the Netherlands are given in figure 2.

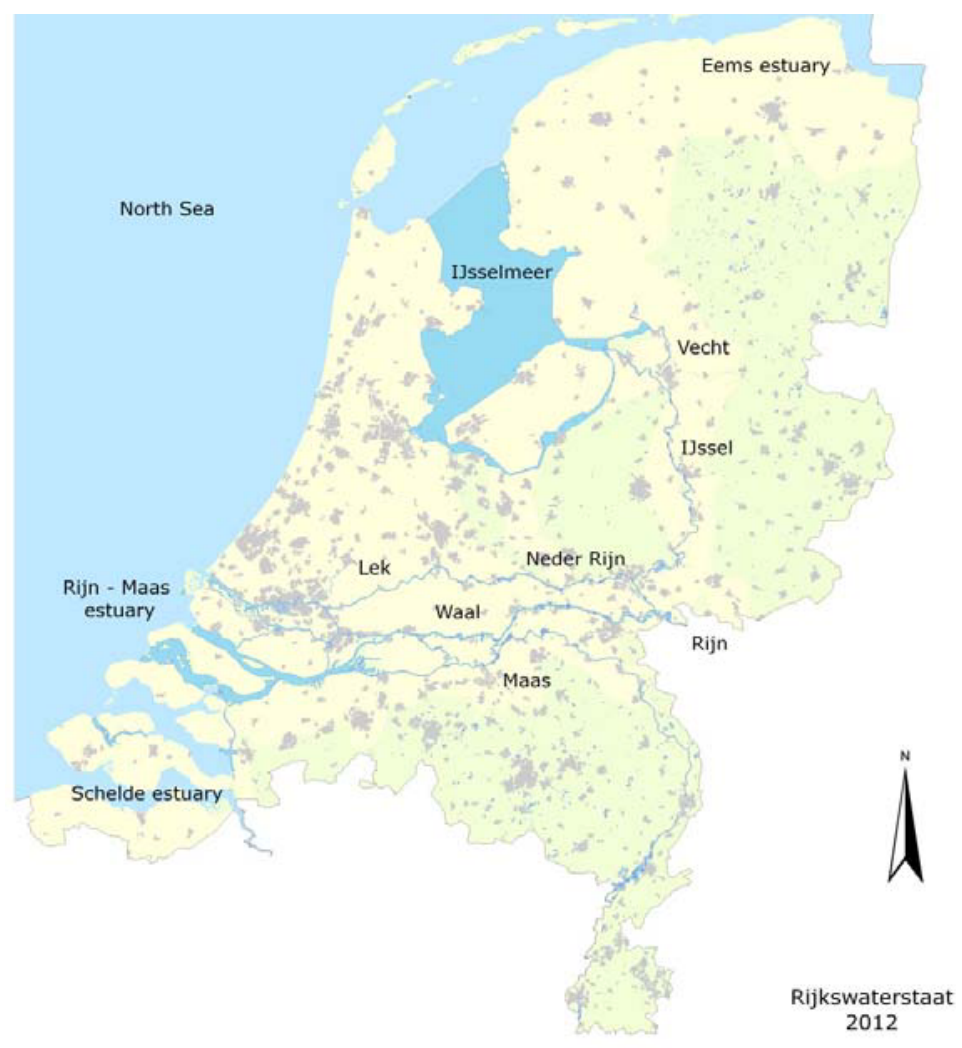

Figure 2. The names of the Dutch water systems

\subsubsection{Storm surge warning for the North Sea}

Storm surge warnings consist of predicted maximum water levels and a general description of the expected wind and tide and the moment of the expected maxima.10 minute water level-forecasts are computed and distributed.

Since 2012 wave action is also forecast in an experimental setup. In the long term this is to facilitate the forecasting of dune erosion on account of water levels for forecasting and waves and wave run-up and wave overtopping for dikes.

\subsubsection{Flood forecasts for Rivers,}

The flood forecasts for the Rhine River (at Lobith) and for the Meuse river at (Borgharen and recently Sint Pieter) are given in water levels and discharges at the stream gauges. There is a 10 day forecast from the National Meteorological office for precipitation. Using precipitation and river gages upstream the current lead time is 1 to 2 days for the Meuse river and 3 days for the Rhine River (see figure 3) depending on where the rainfall event took place.

Forecasts for rivers have become more and more reliable through the use of ensembles (figure 4).

The Regional Centres at Maastricht, Arnhem and Rotterdam inform different services about the forecast for the water levels along the rivers. 
For the Meuse river and the Rhine River and the three Rhine branches ("Waal", "IJssel", "Nederrijn/Lek") the maximum water levels and the moment of the maximum water levels are given at every kilometre in the middle of the river and for the gauging stations, situated every 30 kilometres along the river..

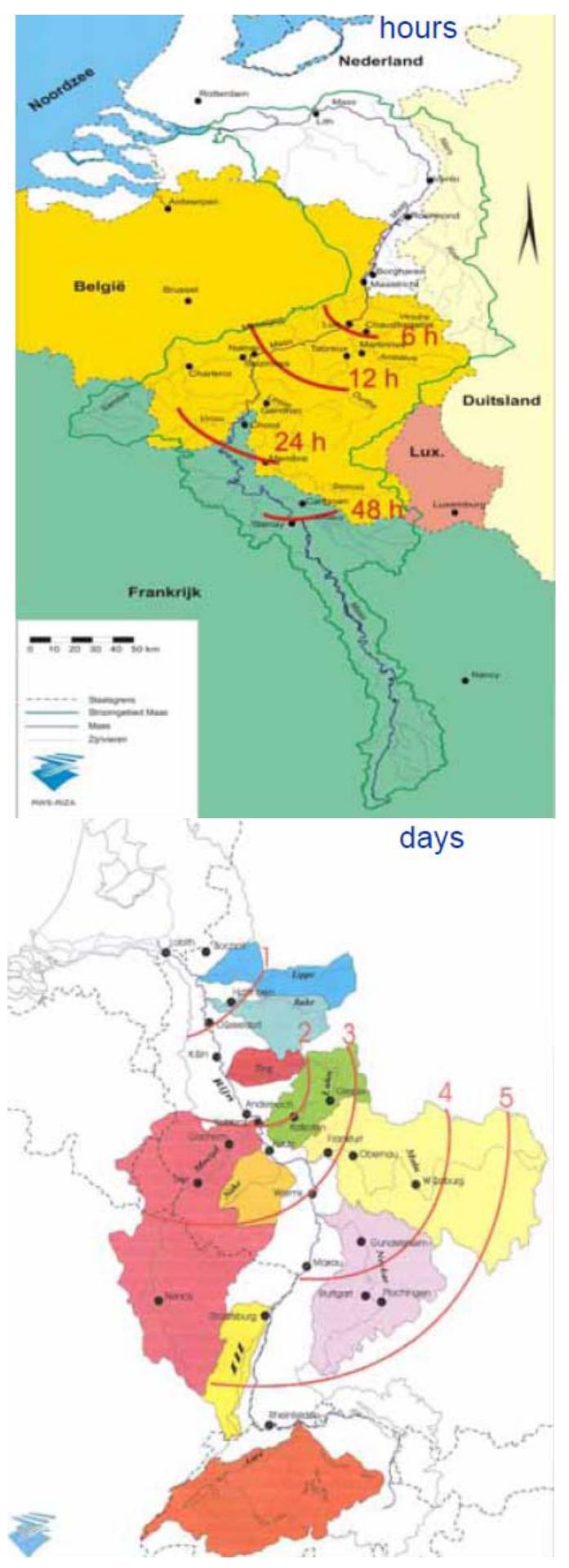

Figure 3. Lead time for the Meuse and Rhine Rivers at the stream gauges at Borgharen and Lobith, [Sprokkereef, 2010]

For the Rhine-Meuse Estuary flood warnings and storm surge warnings are combined. The maximum water levels and the moment of the maximum water levels are given. Hydraulic loads from wave action are large, but are not given.

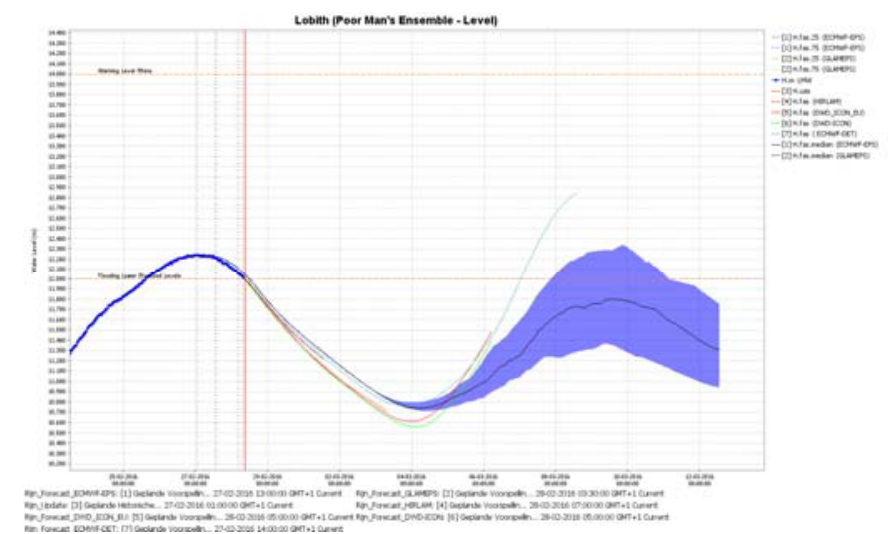

Figure 4: Example of the result of 50 ensembles for the Rhine River (FEWS model), February $28^{\text {th }} 2016$

\subsubsection{Forecasts for Large lakes}

The WMCN-lakes model is the most elaborate. It provides hydraulic loads for each flood defence in the Ijssel lake and Marken lake area, and the three tributaries: the Eem river, the IJssel river delta and the Vecht river delta. It is what the Netherlands should provide in the near future for all the water systems. Uniform flood forecasting information for all water systems makes all subsequent processes more efficient and reliable. KNMI, the national Meteorological service provides downscaled wind with the HIRLAM model ${ }^{\mathrm{b}}$, High Resolution Local Area Modelling for numerical weather prediction. [Unden et al, 2002]. Using the WAQUA model [Rijkswaterstaat, 2012], storm surges are calculated for the lakes and three river deltas. Subsequently using the SWAN model [Zijlema, 2007] wave height, wave periods and wave direction are calculated. And finally using foreshore model [de Waal, 1999] (not shown), the wave run-up model [van der Meer, 2002] the hydraulic loads and wave overtopping are calculated. The model chain (figure 5) which was introduced in 2007 has been described in detail by [Genseberger et al, 2013].

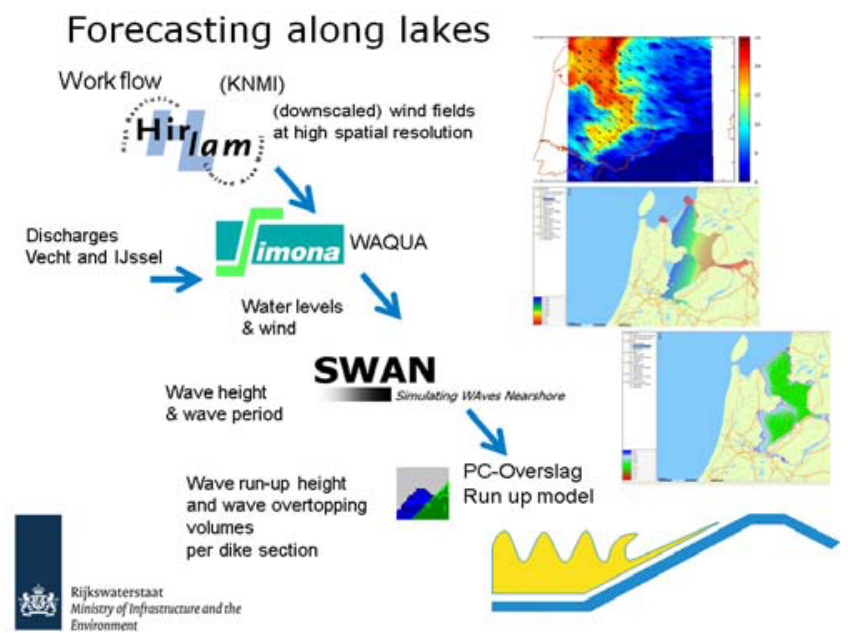

Figure 5. Workflow for flood forecasting along large lakes [Genseberger et al, 2013] and [Slomp, 2012]

\footnotetext{
${ }^{\mathrm{b}}$ HIRLAM is being replaced by HARMONIE
} 


\section{Interpreting data from flood forecasts}

Interpreting data from flood forecasts is cumbersome. There are $3600 \mathrm{~km}$ of flood defences. To simplify the production process and understanding flood alerts the focus has been on water levels. For policy studies if a given design water level of a dike or structure is exceeded it is considered to fail. Reality however is more complicated. Flood defence managers will do everything possible to stop this from happening. In wind driven systems like the sea or large lakes height of a flood defence can be 10 meters or more above the design water level. Design water levels and design heights usually not correlated [Geerse, 2011]. In the Netherlands the only exception is for large straight coasts like the Dutch dune coast with its large dikes e.g. Pettenmer- and Hondsbossezeewerng closing the former passages between the dunes. Correlation between waves and water levels is very high for the Dutch coast[den Heijer et al, 2008]. So for most area's giving only information on water levels is not sufficient and can provide misleading information.

Information on the link between probability of flooding and flood extent can be provided by policy studies .

How a breach will develop remains a second large question to answer. Some breaches widen very vast, other remain small (and can be rapidly plugged by a ship, e.g. in 1953) [Slager, 2010]. Other breaches deepen and widen at the same time leaving immense scour holes, impossible to fill during a flood event and almost impossible to block.

The size of the breach and the size and the layout of the area behind the breach determines speed and extent of flooding. Secondary dikes or (rail)roads or other high obstacles can slow the extent of a flood, but often increase the flow rates and rising rates of water levels and thus the number of casualties.

\section{Information from policy studies and formal assessment of flood defences.}

\subsection{The role of probabilistic models for design and assessment of flood defences}

Since 1980 probabilistic design studies have been carried out in the Netherlands [Vrijling and Bruinsma, 1980]. Swiftly after this simple probabilistic models for hydraulic loads were quickly developed for assessment of flood defences in coastal areas and rivers. In river areas water levels and waves are fully independent. A semiprobabilistic model was developed in 1985 [Dillingh and Cappendijk, 1985]. In coastal areas like the dunes and dikes along the shore of Holland (the western provinces) there is almost a full correlation between water levels and waves (as mentioned above). For dikes a model was developed in 1990. This model was replaced by the Hydra-K model in 2001 [den Heijer et al, 2008].

For complex systems like lakes with both wave action and water levels but no river discharges a probabilistic Hydraulic Load model was also developed in 1994
"Peilof". This was replaced by the model Hydra-M [Westphal and Harman, 1999] in 1998.

For complex systems with storm surge barriers tailor made models were developed by the teams involved. Each storm surge barrier generated a group of independent and sometimes competing model developers.

- Eastern Scheldt Barrier in operation in 1985

[Vrijling and Bruinsma 1980]

- Rotterdam Storm Surge Barrier in operation in 1997

[de Deugd, 1995]

- Ramspol Storm Surge Barrier 2002 [Kors et al, 1994]

The institute for building codes "CUR", the technical Advisory Committee on flood Defences (TAW) and the national government provided a document in English on progress in the development of probabilistic models in 1990 [CUR, 1990].

In 1994 for the design of the Rotterdam Storm surge barrier a probabilistic model was used to provide design water levels "Freqfk" [de Deugd, 1995]. Then a probabilistic strength model "Dijkring"[den Heijer et al, 1995] was used to determine the Hydraulic loads on flood defences using a "wave run up failure mechanism". Both the National and Regional government developed their own models. For maintenance of Storm surge Barriers the National Government developed the "PROBO" model. This considers the whole fault tree of a storm surge barrier.

Around 1994 for the evaluation of the strength of Flood Defences the Technical National Research institute (TNO) developed the model PC-ring [Vrouwenverlder et al, 2001]. This model combined both the hydraulic load models and the strength models. Since the model covers a lot of different fields it is complicated and uses a lot of general descriptions for stochastic processes. The model works and has been used in the VNK-I / the national flood risk study from 2001 to 2006 and in the VNK-2 study from 2007 to 2014 [Jongejan et al, 2011].

In 1996 a new suite of probabilistic models for hydraulic loads were launched. This model suite has been described by [Geerse, 2011] and [Slomp, et al 2014]. The PC-ring and Hydra-suite of probabilistic models will be integrated in 2017 in Hydra-Ring [Roescoe et al, 2012].

\subsection{Data from risk analysis studies}

The main two national policy studies which provide flood risk information are WV21/DPV [Kind, 2010] and VNK2 [Jongejan et al, 2011]. The WV21 study (flood risk analysis for the 21 st century) carried out a flood risk assessment for the Netherlands for three future scenario's 2015, 2050 and 2100. To calculate failure probabilities the probabilistic formal flood defence assessment tools of 2011 were used. The goal was to determine new flood risk standards to replace the standards developed since 1960. Climate change and economic growth were important variables in this study. Large river enlargement projects like room for the rivers were taken into account. The probability of flooding was determined using the failure modes overflow and overtopping, the Hydramodels [Geerse, 2011]. 
Simultaneously the VNK2 was carried out, a second national flood risk assessment. The VNK2 study determined the actual flood risk, the reference data differed per area from the year 2010 to the year 2014. This is the situation before a number of large reconstruction projects (e.g. Room for the River and HWBPII (the national flood defence reinforcement programme 2011-2015 ) were completed. Flood probability was determined using a full probabilistic model and the main failure modes for flood defences. The failure modes are geotechnical failure (piping and inner slope failure), outer revetment failure (gras, asphalt and stone) and subsequently failure of the underlying layers, overtopping and overflow and subsequent erosion of the inner slope for dikes for dikes, dune erosion for dunes, overtopping, structural failure, non-closure, stability (and piping) for hydraulic structures. Flood damages in the WV21 and VNK-2 study were determined using overland flow models [Duinmijer, 2002] and flood damage curves [Kok et al, 2005].

\subsection{Other policy studies}

Other policy studies were often carried out in smaller area's but can also provide valuable additional information. This information still has to be filtered and added into the MEGO/LIWO database.

- The cross boundary flooding along the Rhine is an important issue not included in national flood risk analysis studies. This was separately investigated in a common project with the German federal state North Rhine Westphalia between 2005 and 2009 [Silva et al, 2009]

- The effect on flood probability due to the Room for the River and Meuse Works projects on the Rhine and Meuse rivers. Both projects have lowered the design water levels. This study uses both prototypes of Hydramodels and fragility curves to determine the probability of flooding [VenW and BZK, 2006]

In 2007 and 2008 the National Risk Assessment by the ministry of Interior in the Netherland [BZK, 2008] was carried out. For each worst credible flood (figure 1) evacuation policies were assessed. and a strategy was determined to reduce loss of life. It became clear that evacuating the urban population of the Western Coastal areas in the Netherlands was not possible [HKV and Orangewoud /Save, 2008], [Brinke et al 2010] and [Slomp and Kolen, 2011]. A National Exercise [TMO, 2009] was prepared and carried out using tools developed by [HKV and Orangewoud /Save, 2008].

[Kolen, 2013] shows that a mixture of horizontal evacuation (getting out of the area at risk) and vertical evacuation (getting to safe areas near or in your own residence) is more appropriate. To reduce the maximum number of casualties all available resources have to be used most efficiently. For each region using the worst credible flood scenario the most important activities and capacities were identified and the number of necessary units of emergency services per region was calculated. Evacuation models were used to determine the flow of spontaneous and organised evacuation and the possibility to evacuate in a certain time frame. Flooding scenarios show which area is the most vulnerable (figure 6). The population per area was determined and separated into self-reliant and non-self-reliant (figure 7). As measures both horizontal (removal from the area) and vertical evacuation (in the building itself or to nearby high ground or buildings) was considered. The tasks for the emergency services were focussed on reducing the number of fatalities and promoting the self-reliant people to carry out what they can do to survive on their own.

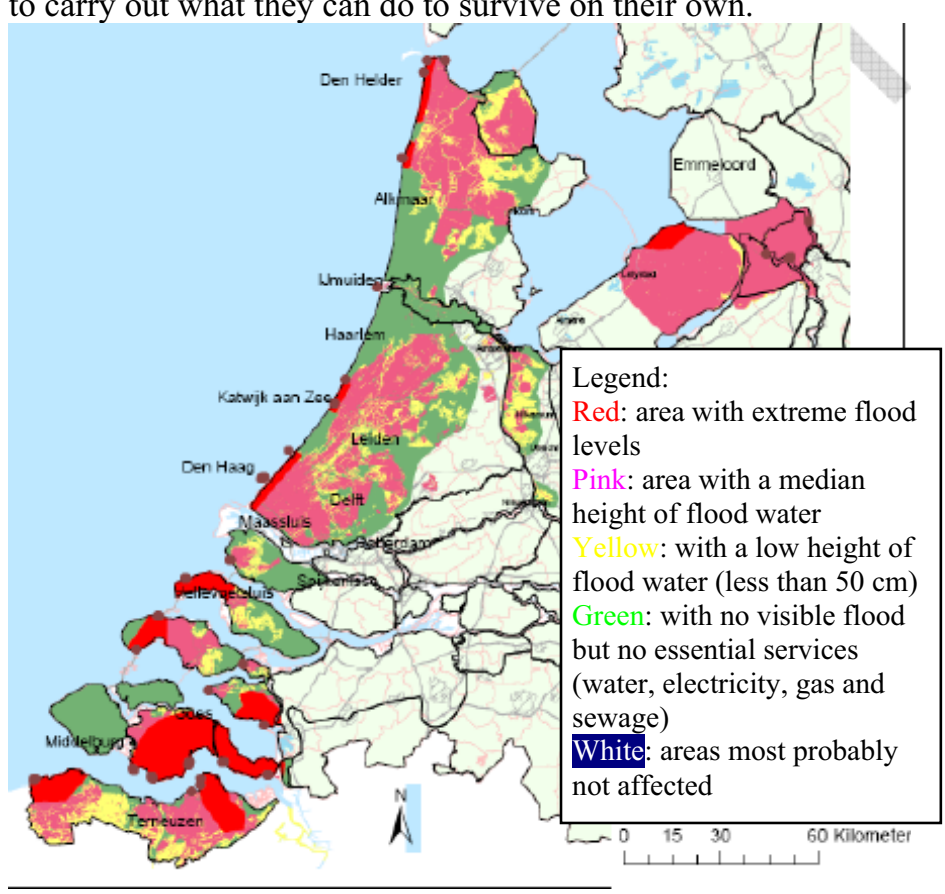

Figure 6. division of the flood scenarios into areas with different flood heights or effects of the flood.

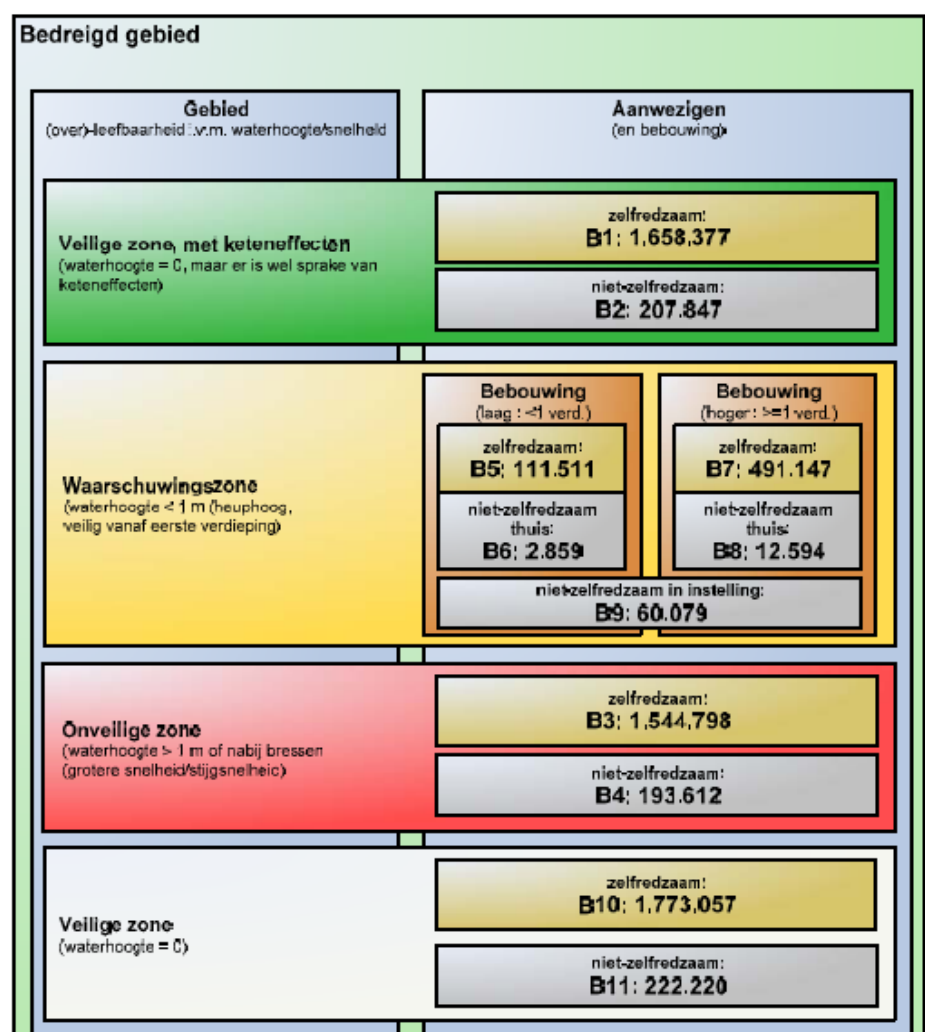

Figure 7. division of the number of people per category per area (of figure 6) 


\section{Other important digital geographical data sources}

The MEGO/LIWO database combines and structures data from open sources to use during a crisis and to inform the public on flood risk. The main sources are: -Registry data, http://www.kadaster.nl/web/english.htm -PDOK data. Public services on a map, publieks dienstverlening op de kaart (in Dutch) Topographic and mapping data, see the pdok viewer http://pdokviewer.pdok.nl/

-Flood Scenarios databank ${ }^{\mathrm{c}}$,

o Data on water levels after flood defences fail

o Data on water levels in non-protected areas along rivers, lakes and the coast

Note there is also other public domain information available e.g. Digital road maps ${ }^{\mathrm{d}}$ :

The main three sources of information the Registry, PDOK and flood scenario's will be covered below.

The registry data, a public body of the ministry of Infrastructure and the Environment consists of information on the ownership, use of a building and value of a building or plot of land. Some of the information belongs to other public bodies (e.g. local, regional or national governments) but is managed by the registry. Having a central unique data source helps.

The most important databases maintained by the national registry are:

-BAG : Basis registratie Adressen en Gebouwen (in Dutch), data about the address of a building, date of construction, building size, available surface area of the building $\left(\mathrm{m}^{2}\right)$, use of the building public, private (commercial, public, utilitarian or private), which permits for use a given (e.g. if you can use it as a live in)

-BRK: "Basis Registratie Kadaster" (in Dutch), basic registration of the Registry, ownership data, mortgages/ debts linked to the building

-WKPB, restrictions on land use, All formal national, regional and local restrictions on the use of land are registered at the Registry. This is based on the act "Wet kenbaarheid publiekrechtelijke beperkingen onroerende zaken (WKPB)"

-BWOZ, a data base belonging to all local governments which contains the annual appraisal data derived by local governments. This combined information is used by national, regional and local government to annually set property value taxes and to set income taxes based the value of income and the persons total assets at the beginning of each year.

-KLIC (WION) The national registry of pipelines and cables The main purpose of the database is to avoid disruption of service due to broken cables /pipes because of new construction. This is also important information to determine if public service still work after a flood.

-Ruimtelijkeplannen.nl, A data base with all future plans ${ }^{\mathrm{e}}$ -Rijksdriehoekstelsel, the national Geodetic Datum System . The registry is responsible for maintaining the national Datum, the coordinate structure for mapping in

\footnotetext{
${ }^{\mathrm{c}}$ http://www.risicokaart.nl/en/

${ }^{\mathrm{d}} \mathrm{http}: / / \mathrm{www}$.openstreetmap.org/\#map=5/51.500/-0.100

${ }^{\mathrm{e}} \mathrm{http}: / /$ www.kadaster.nl/web/Themas/Registraties/Ruimtelijkeplannen.nl.htm
}

the Netherlands, the main sea level reference point for levelling purposes and the 35000 visible markers.

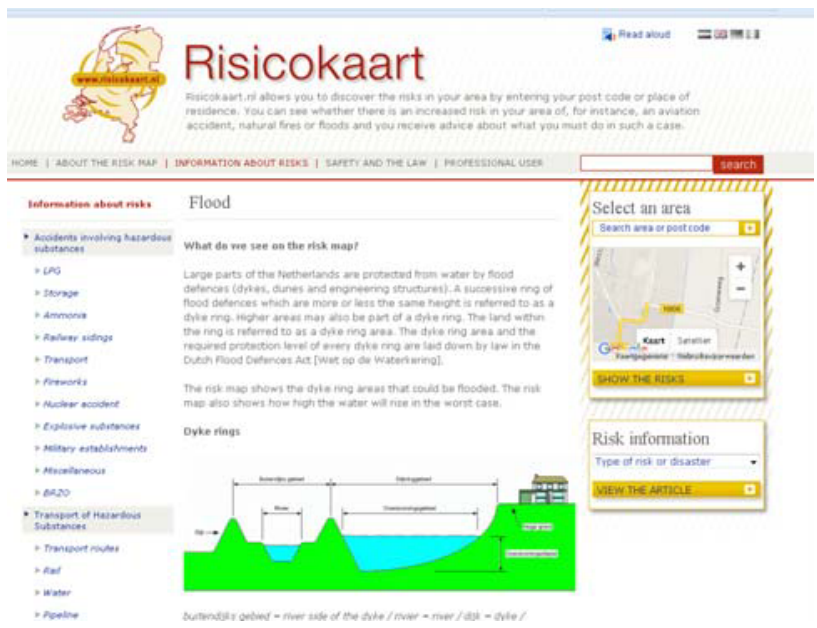

Figure 8. National Risk Map (English pages)

The national online risk $\operatorname{map}^{\mathrm{f}}$ (figure 8) presents hazards for the public and professionals. An association of provinces of the Netherlands IPO (Interprovinciaal Overleg) hosts the website. This shows hazards from transport, industrial risks and natural hazards (Forest Fires, Earth Quakes, Flooding). Data from the HIS and VNK studies were used to fill the website.

CBS data, Central Bureau for Statistics, Centraal Bureau voor de Statistiek. Anonymous information on annual economic activity per city block is available for policy studies.

National postal code data, Postal codes in the Netherlands identify sections of streets. The house number and postal code is the main link between most databases for policy studies.

\section{Increasing risk awareness}

The first use of the information from the MEGO/LIWO model is to inform the public on flood risk and increase risk awareness and the second use is during a crisis. The models enables data selection and making overlays. Overlays were made for each flood scenario to determine which buildings have dry floors and which roads are accessible.

The website "Where do I flood?" was launched in the fall of 2014 (figure 9). Using ones postal code one can see how high water can come during a "design flood" for a return period from figure 1. This information is consistent with the information on Risicokaart.nl, but has a slightly larger database. Using an app and smart phone a person can see the height of the water on account of a flood through his/her camera using an augmented reality projection $^{\mathrm{h}}$ (this is schematised in figure 9a).

\footnotetext{
http://www.risicokaart.nl/en/

${ }^{g}$ www.overstroomik.nl

${ }^{\mathrm{h}}$ A projection augmented model (PA model) is an element sometimes employed in virtual reality systems. It consists of a physical threedimensional model onto which a computer image is projected to create a realistic looking object. Importantly, the physical model is the same geometric shape as the object that the PA model depicts. Wikipedia.
} 


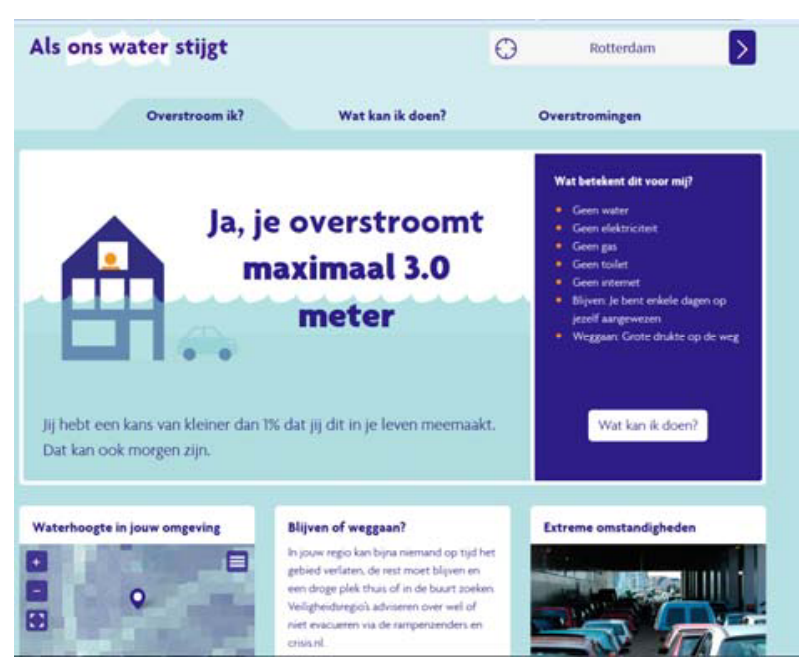

Figure 9.a: website Waar overstroom ik (in Dutch), where do I flood? to determine flood levels in your house

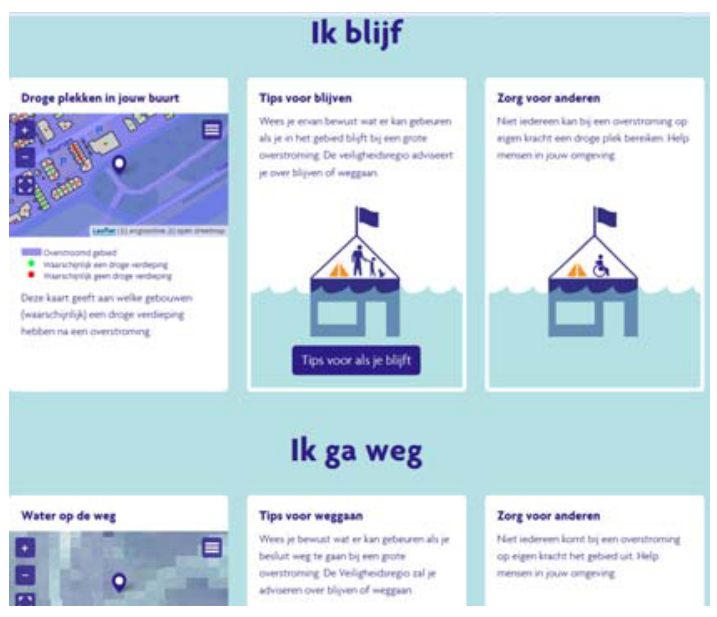

Figure 9b. Website Waar overstroom ik (in Dutch), where do I flood? Tips on what to do if you stay or leave.

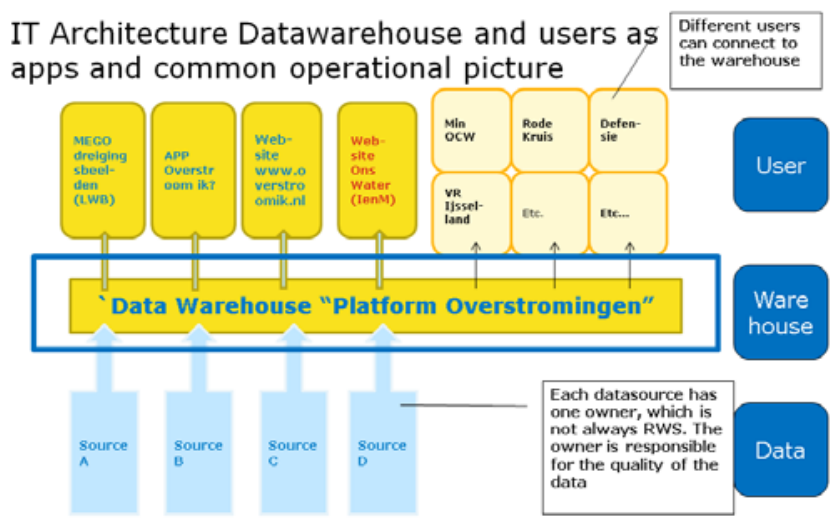

Figure 10. Data warehouse for professionals http://professional.basisinformatieoverstromingen.nl/liwo/

For professionals information in databases is available on dry areas, time of arrival, speed of flooding height of flooding per scenario. Also information from satellites can be added to show flooded areas.

\section{Operational information provided by LIWO}

The WMCN provides formal flood alerts directly to professionals. Through LIWO flood related information becomes available for civilians and professionals alike, since the data are freely available (open data). Customized information can be delivered to different clients, like the general public, the regional water authorities or the safety regions (regional governments responsible for emergency management). The WMCN is responsible for a rapid assessment of the situation during a storm and/or high river discharge and during a flood event. Between 2007 and 2015using GIS programmes, documents and models all the information was available for a small number of experts. LIWO is an essential tool for rapid assessment by more than just 5 to 10 people. This is a major improvement. The first step is using it actively with professionals. There is also a data warehouse for professionals (figure 10).

Expected water levels are available one to four days in advance. For large lakes the information includes wave action, overtopping and wave-run-up heights. Water level information can be translated to maps to indicate areas which are / may be flooded or to indicate water levels in non-protected areas along coasts and the shores of lakes and rivers. About 100000 people in the Netherlands live outside the protection of dikes [Slomp, 2012]. Not all information from the 10 day lead time (see figure 4) is publicly available in LIWO. Part of the information is only available at $\mathrm{WMCN}$ for the professional forecaster to verify the forecast.

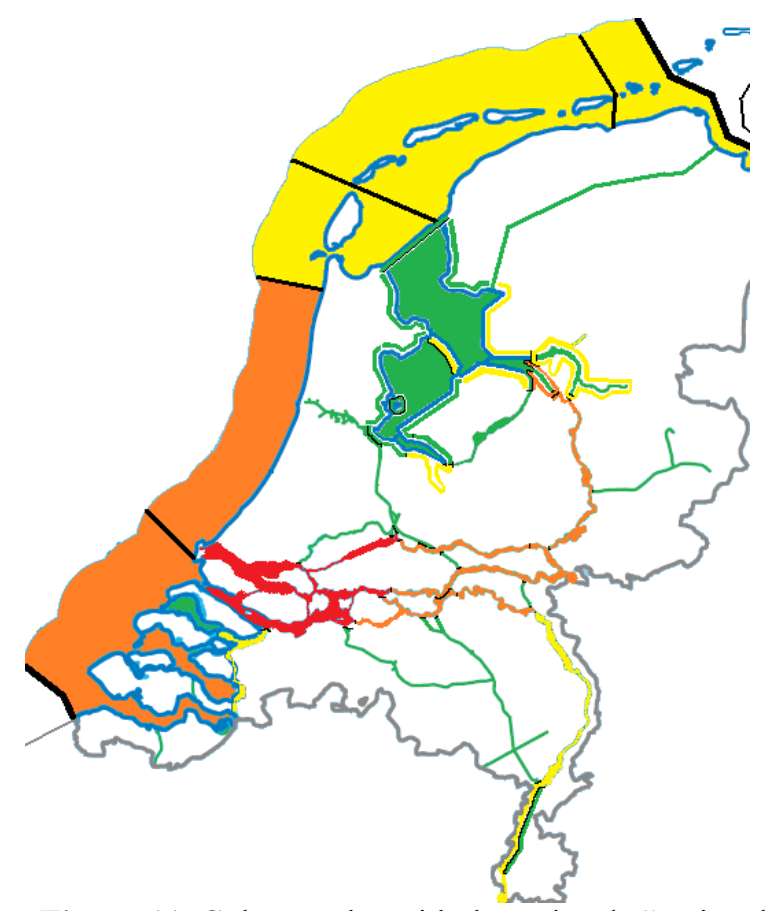

Figure 11. Colour codes with threat levels "national handbook on flood alerts LDHO 
Communication on flood alerts is done using colour codes per region, based on water level information and reliability information on the correctness of the forecast (figure 11). There are four codes: Green no threat, red largest threat, orange, yellow intermediate threat levels. Each forecast includes information on the uncertainty of the flood forecast (the reliability of the forecast) of the expected water level. Threat levels increase as return periods / the probability of flooding increases by a factor 10. Note: forecasts are given for reference points in water systems, e.g. Hoek van Holland, Vlissingen (Flushing) or for the lake area as a whole, see table 1.

Which selections are available in LIWO is summarized below:

- Formal risk-based standards for flood defences (figure 1)

- Threat levels for a certain storm surge, river discharge or combination (figure 11 and table 1)

- Planned reinforcement projects, (not shown)

- Scenario's for flood events (not shown) or the maximum water levels for all scenario's combined (figure 12)

- The probability of failure (according to the VNK-2 study figure 13)

- Formal results from the last, the third formal assessment 2006-2011 (figure 14)

- A selection of validated flood scenario's from the HIS,

VNK, WV21, and Worst credible floods studies

- Time of arrival of the flood in a protected area for each scenario (not shown)

- Evacuation routes (not shown)

- Areas and site with high building which can serve as shelters during a flood (figure 15)

- Flooded and available roads in case of a flood (figure 16)

- Time of arrival of the water for a specific breach scenario

- Rising rate of the water, (not shown)

- Information on large industrial site which are a hazard during a flood, (not shown)

- Information for the managers of critical infrastructure (not shown)

\begin{tabular}{|c|c|c|c|}
\hline Sector & $\begin{array}{l}\text { Cod } \\
\left.e^{*}\right)\end{array}$ & $\begin{array}{l}\text { Epected water level } \\
(+\mathrm{NAP}) \text { or discharge } \\
(\mathrm{m} 3 / \mathrm{s})\end{array}$ & $\begin{array}{l}\text { Marimum levels will be expected at } \\
\text { time, date }\end{array}$ \\
\hline \multicolumn{4}{|l|}{ KUST/Coast } \\
\hline Scheldt Esutuaries & & & $\begin{array}{l}\text { Example Tuesday Ocotber } 17^{\mathrm{n}} \text { at } 03: 30 \\
\text { hours }\end{array}$ \\
\hline $\begin{array}{l}\text { Dordrecht/Rijn } \\
\text { Estuary }\end{array}$ & & $2,85(+/-0,10)$ & \\
\hline West Holland & & $3,70(+/-0,20)$ & \\
\hline \multicolumn{3}{|l|}{ Den Helder } & \\
\hline Harlingen & & $\begin{array}{l}\text { lectoren due green zzyn in is } \\
\text { tz.t. we glaten!le (kaartje is } \\
\text { ook al compleet) }\end{array}$ & \\
\hline \multicolumn{4}{|l|}{ RIIEREN/Rivers } \\
\hline Rijn & & Lobith: $9000 \mathrm{~m}^{3} / \mathrm{s}$ & $\begin{array}{l}\text { Moment van de piek en hoe lang hij } \\
\text { aanhoudt }\end{array}$ \\
\hline $\begin{array}{l}\text { (Rjin, Waal, Isssel, } \\
\text { Nederijn, Lek) }\end{array}$ & & $\begin{array}{l}\text { Water level: } \mathrm{xx}, \mathrm{xx}+\mathrm{m} \\
\text { NAP }\end{array}$ & \\
\hline $\begin{array}{l}\text { Maas } \\
\text { St. Pieter - Lith }\end{array}$ & & Afvoer: $700 \mathrm{~m}^{3} / \mathrm{s}$ & \\
\hline \multicolumn{4}{|c|}{ MIEREN/Large Lakes } \\
\hline \multicolumn{4}{|l|}{$\begin{array}{l}\text { Ijssel delta } \\
\text { Vecht delta }\end{array}$} \\
\hline \multicolumn{4}{|l|}{ Ijssel Lake } \\
\hline \multirow{2}{*}{\multicolumn{4}{|c|}{$\begin{array}{l}\text { Lake Marken } \\
\text { KANALENAain }\end{array}$}} \\
\hline & & & \\
\hline
\end{tabular}

Table 1. Colour codes with threat levels based on the national handbook on flood alerts LDHO

Information on the actual probability of flooding for

flood defences will come available progressively

from 2017 onwards, during the $4^{\text {th }}$ formal assessment 2017-2023.
Measures to be taken /information to be exchanged

To know which spots are the weakest means that staff can be propositioned in advance to these spots, to monitor these flood defences continuously.

Information on the threat level for weak spots (e.g. bases on conditional probabilities) can be communicated by the regional water authority to LIWO.

Also information on damages to flood defences during and after a large event collected by the regional water authority can be assembled through LIWO to provide a national overview rapidly.

Information on damages and flood extent can be supplemented using aerial photographs or satellite pictures if a flood takes place.

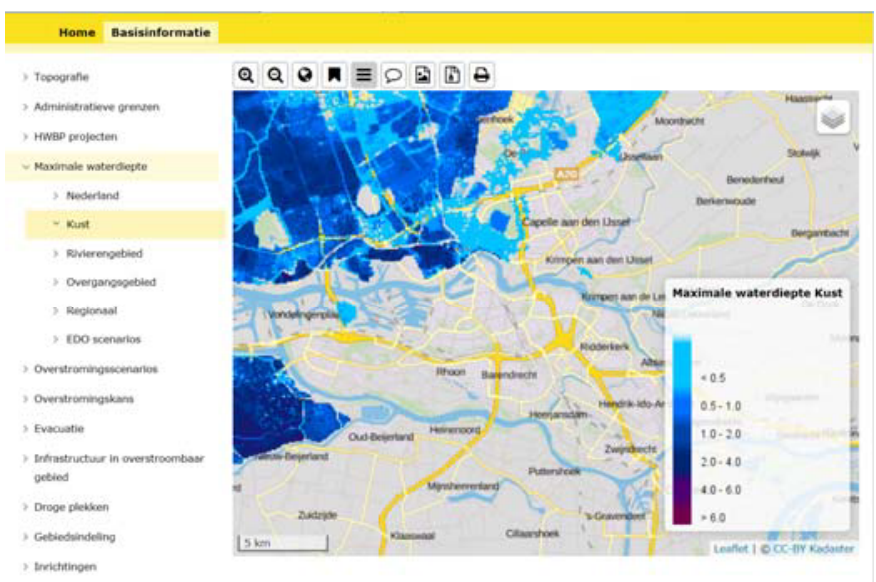

Figure 12. Scenario of a flood maximum water levels for all coastal flood scenarios ${ }^{\mathrm{i}}$

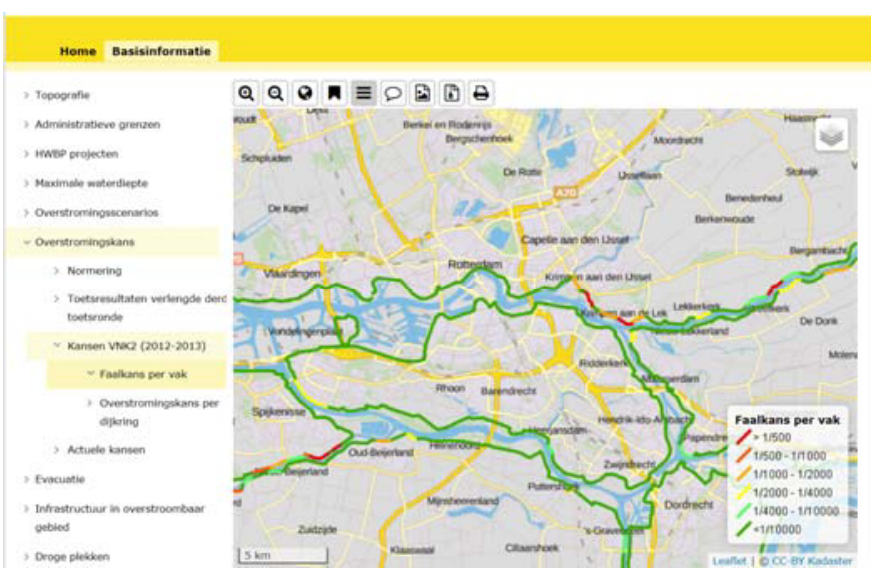

Figure 13. current probability of failure for flood defences "Rotterdam area", VNK-policy study ${ }^{j}$

note this is physically not possible.

${ }^{\mathrm{j}}$ note the figures are not absolute, this was a policy study. 


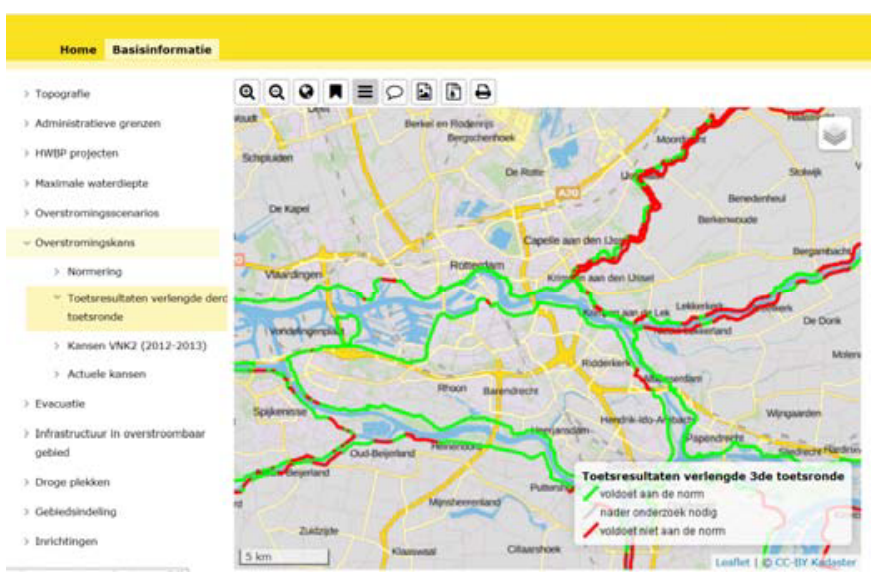

Figure 14. results from the third formal assessment 2006-2011

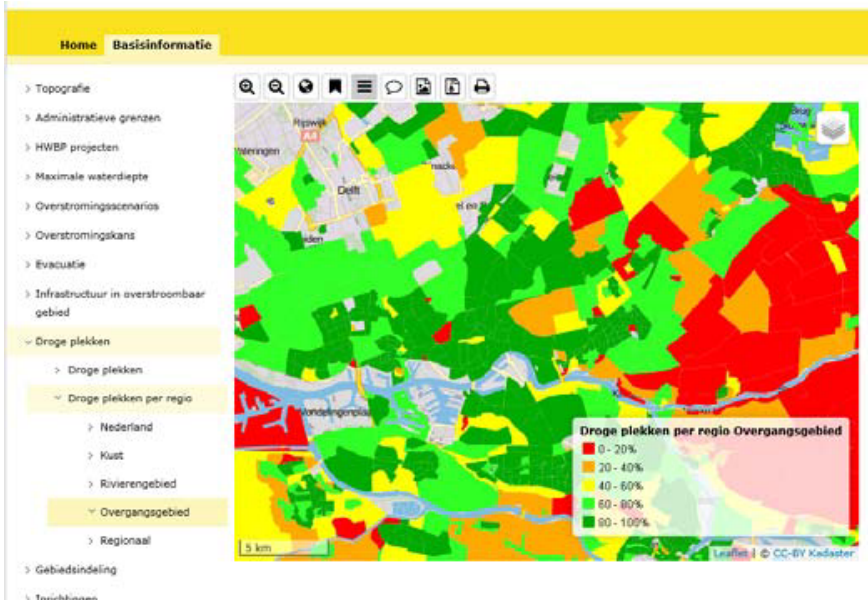

Figure 15a. Available dry areas to use as shelter in account of a flood, "Rotterdam area" per zone

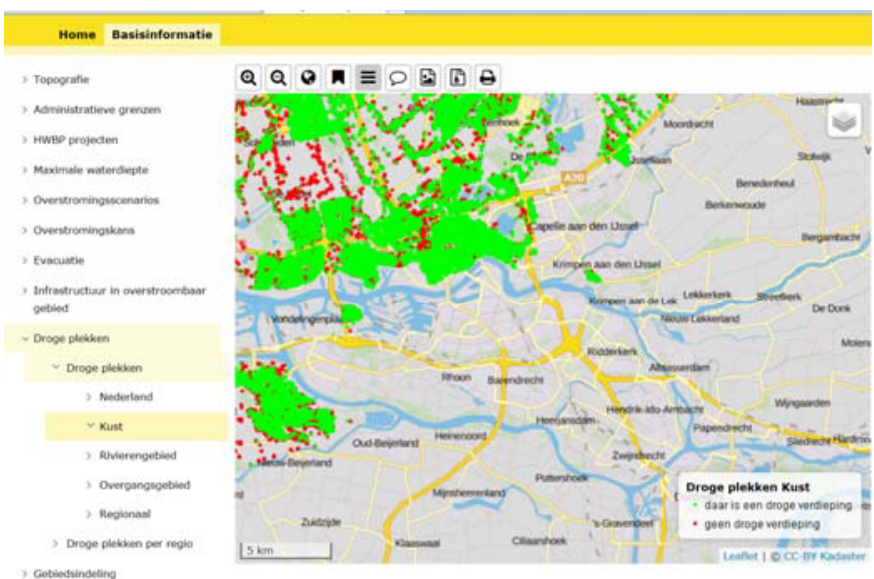

Figure 15b. Possible available dry areas to use as shelters in account of a flood, "Rotterdam area" per "shelter" Possible shelters were identified based on the maximum flood levels of all available scenarios, and the available information from the national registry on buildings types and heights were identified

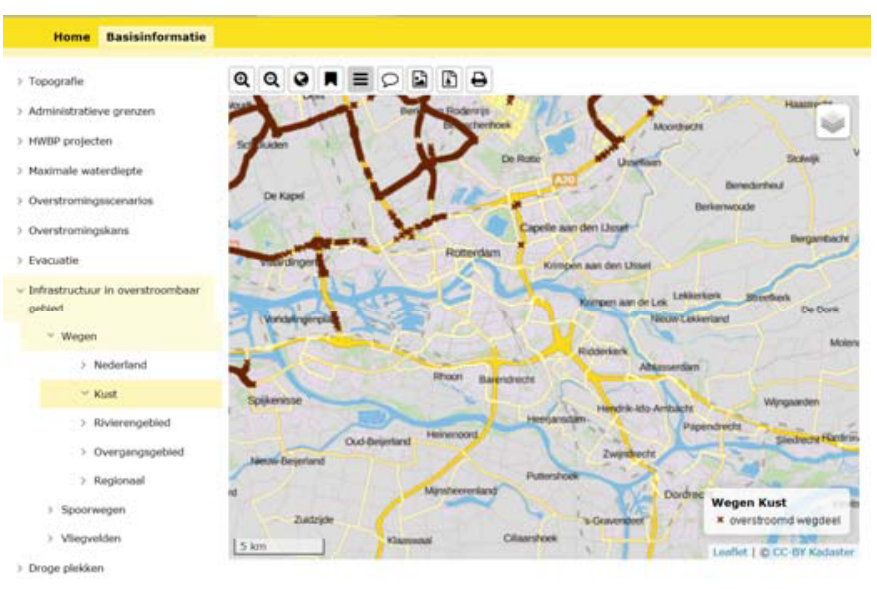

Figure 16. Available infrastructure after a flood (note : brown cross means not available)

\section{Applicability abroad for these tools}

What does this mean for other countries with less information available on line and in past research LIWO is an open source model and can be filled with information from any country in the world.

The minimum information needed is:

-a good description of the water system. forecasting models as FEWS can be set up easily and at low cost for large areas, e.g. Ghana on the Volta river. The most important information is available at (inter)national weather centres.

- rainfall prediction (for river floods)

- wind prediction (for estuaries, the coast and large lakes)

- tidal data

-a digital terrain model

-damage and casualty data can be determined if you combine information from a census or survey with occupation maps (or satellite information)

-the use satellite maps of flooded areas

-means to treat information form social websites

An alternative for flood forecasts is the $\mathrm{EFAS}^{\mathrm{k}}$ information from the European Union Early Flood Alert system. Data is available to national authorities. The level of accuracy is less than making a detailed local hydrodynamic model. The most important information that people and property are at risk is however communicated. The European Union is making a similar system to cover the whole globe GLOFAS. Getting forecast information to the public on time and with information how to react will be the most important challenge to fulfil.

Flood forecasting is necessary to save lives and reduce damages. Reducing damages is important to save livelihoods and to reduce the recovery time. Flood alerts should contain time of the event, location and extent of

${ }^{\mathrm{k}}$ https://www.efas.eu/ 
the event. A flood alert is not only one message but part of a rehearsed flow of information using multiple canals. First people have to accept the fact that there might be a threat and what the threat is about. People need a reference to understand the situation and be aware of possible measures they can take assure their own safety and reduce damages. Information to the general public has to be consistent with the information used by emergency services and has be very clear about consequences and context of possible measures (as shelter in place or preventive evacuation). Emergency services should monitor how the public is responding to adapt their communication en operation during a crisis. Flood warnings and emergency services are often coordinated by different government organisations. This is an extra handicap for having consistent information out on time for people to use. We may have to trust the public more and send out the correct information as it comes in.

\section{Giving the public and professionals information to act on}

For river floods and with relatively high probability events like a $1 / 100$ year storm surge it is possible to have teams on the flood defences for inspection purposes. Overflow and overtopping are relatively easy to see and to predict in a reliable fashion. But geotechnical failure modes remain difficult to observe and predict. For Dutch current and future standards for flood defences on the coast respectively a 10000 year and a 100000 year event [Slomp, 2016] an accurate real-time forecast for failure will almost be impossible to provide. The FEWSDAM model of the flood control project has experimented in combining the flood forecast and information on the flood defence. The FEWS-DAM model [Deltares, 2012] in the "Flood Control program" [Lam et al, 2013] provides information on the probability for failure for piping and slope stability using information from the FEWS forecast (see paragraph 2.2.3). The proof of concept was tested in the Vecht and IJssel river delta's.

The national coordinating committee for floods will collect and disseminate information from and for managers of flood defences and for the safety regions. The new LIWO model will provide essential information rapidly for crisis management and make information available for the public and professionals

Information on the strength of flood defences is available from regular inspections, policy studies since 2001 (VNK, RBSO, WV21, see paragraph 4) and the most recent flood defence assessment study of 20062011. The most important choice to make in the future is letting go. Accepting that many of the models used are reliable and providing sufficient information through online-real-time services. In the near future more and more models can be used for real-time forecasting.

\section{Concluding remarks}

Flood forecasting and information on the precise consequences per flood has developed over time in the Netherlands. Statistical data have been used for flood forecasting in the past, later on data bases with scenarios were used, now real time forecasting models are possible. Interpreting flood alerts and giving the probability of failure of a flood defence and predicting how and area will flood and how much damage and casualties will be caused is still based on databases from policy studies. The next step will be to create a reliable chain of models which can predict the probability of the failure of a flood defence and the extent of flooding in real time.

The models are available, creating a reliable chain in the challenge. Adding temporal information for hydraulic loads and strength of flood defences is essential for this to succeed. Additionally it will take a lot of data from observed floods, flood defence failures, real size experiments and model simulations for models to be reliable enough for this step, to forecast in real time.

\section{References}

Ministry of Internal Affairs, BZK, (2008), National Security Strategy and work programme 2007-2008 http://english.minbzk.nl/subjects?ActItmIdt=106955

Bogaard J. van den, Akkeren K. van (2011), Leidraad risicogestuurd beheer en onderhoud conform de ProBO werkwijze; Ministerie van Infrastructuur en Milieu, Rijkswaterstaat, Steunpunt ProBO,

Booij, N., Herbers, T.H.C.,Holthuijsen, L.H. The shallow water wave hindcast model: HISWA Part II: test cases (1985)

Brinke, W.B.M., Kolken, B., Dollee, A., Waveren, van H., Wouters, C.A.H., (2010). Contingency planning for large-scale floods in the Netherlands. Journal of Contingencies and Crisis Management, 2010, 18. 1, http://onlinelibrary.wiley.com/doi/10.1111/j.1468-

5973.2009.00594.x/abstract

CUR (1990), Probabilistic design of flood defences, Center for applied research in construction, Civieltechnisch Centrum Uitvoering Research en Regelgeving, CUR, Rotterdam, The Netherlands

van Dantzig, D. (1956), Economic decision problems for flood prevention, Econometrica 24: 276-287,

Delta Committee, Deltacommissie (in Dutch) (1961) Rapport Deltacommissie 's-Gravenhage; 1960-1961; Staatsdrukkerij- en Uitgeverijbedrijf; Part I: Final advice: Eindverslag en interimadviezen. Part II-IV: Analysis of storm surges and tides, Beschouwingen over stormvloeden en getijbeweging. Partl V: The Deltaplan and its effects, Onderzoekingen betreffende de opzet van het Deltaplan en de gevolgen van de werken. Part VI: Design of dams and dikes, Onderzoekingen van belang voor het ontwerpen van dijken en dammen; Social and economic aspects of the Delta Plan, sociaal-economische aspecten van het Deltaplan

Deltares, (2012) | R\&D Highlights 2012, Esch van J. pag 24. 
Deltares, (2016) SOBEK Hydrodynamics, Rainfall Runoff and Real Time Control, User Manual, 2016

Deugd de H,. (1995) Het optreden van hoogwaterstanden in het noordelijk deltagebied in de situatie met toekomstige infrastructurele aanpassingen. RIZA \#94.014X Rijkswaterstaat,

Dillingh. D, Cappendijk P. (1985) Ontwerpwaarden voor de windsnelheid bij het ontwerp van rivierdijken, COW

Doef, Van der M., Holterman, S.R., Schreuder, M., Van Maarseveen, M., Zuidgeest, M. en Van Zuilekom, K. (2004). De Evacuatie Calculator: een hulpmiddel bij de organisatie van preventieve evacuaties van dijkringgebieden, DWW, Rijkswaterstaat.

Duinmeijer, S.P.A (2002) Verification of Delft FLS,

Geerse C.P.M, (2011) Hydra-Zoet for the fresh water systems in the Netherlands Probabilistic model for the assessment of dike heights,

Genseberger M., Smale A.J., Hartholt (2013) H. Realtime forecasting of flood levels, wind driven waves, wave runup, and overtopping at dikes around Dutch lakes Floodrisk conference 2012

Heijer F. den, Venema, J.E. Cappendijk-de Bok A.M. (1995), “User manual Dijkring, "Programma Dijkring 4.0 : gebruikershandleiding" Rijkswaterstaat Dienst Weg- en Waterbouwkunde (RWS, DWW); Delft : RWS, DWW, 06-1995

Heijer, den F, Vos, R. and Gautier C. (2008) Probabilistic approach for safety assessment of water defences along the Dutch coast, model and verification, ICCE 2008

Jongejan, R.B., H. Stefess, N. Roode, Horst ter W. and. Maaskant, B, (2011): The VNK2-project: a large scale quantitative flood risk analysis for The Netherlands. 5 th International Conference on Flood Management (ICFM5), 27-29 September 2011, Tokyo-Japan

HKV and ORANJEWOUD/SAVE

(2008) Capabilities Based Planning of the Worst Credible Floods, "Capaciteitenplanning - Ergst Denkbare Overstromingssccenario's" (in Dutch). Study carried out for Slomp R. by : Heemskerck F, Kolen B. Jaap van der Schaaf, van der,

Vergouwe R (editor), (2014)The National Flood Risk Analysis for the Netherlands, Rijkswaterstaat VNK http://www.helpdeskwater.nl/onderwerpen/waterveilighei d/programma'-projecten/veiligheid-nederland

Kind, J. (2010)Cost-benefit analysis for flood protection standards in the Netherlands, Deltares,

Delft, The Netherlands, 2010

Kok M., H.J.. Vrouwenvelder A.C.W.M., Barendregt, A. (2005) Standard Method 2004, Damage and Casualties Caused by Flooding, DWW (Rijkswaterstaat)

Kolen B.and Geerts, A (2006) Als het tóch misgaat, Overstromingsscenario's voor Rampenplannen, Betooglijn Worst Credible Floods, 2006.

Kolen, B. (2013) Certainty of uncertainty in evacuation for threat driven response. Principles of adaptive evacuation management for flood risk planning in the Netherlands

Kors A. et al, (1994) Projectnota MER Ramspol Hydrualische Randvoorwaarden, Hydraulic Loads
Ramspol storm surge barrier, working group on Hydraulics (in Dutch)

Lam K.S., Gill P.W., Zwang L.W.A. (2013) Implementation of new levee strength modules for continuous safety assessments, Flood Risk 2012

Meer, van der J. (2002), Technical report wave run-up and wave overtopping at dikes.TAW

OECD (2014) Studies on Water, Water Governance in the Netherlands, Fit for the Future?

Rijkswaterstaat, (2012) WAQUA/TRIWAQ -two- and three-dimensional shallow water flow model.Technical documentation SIMONA report number 99-01, 2012

Roscoe, K. Diermanse, F.,. Lopez de la Cruz J,. Steenbergen, H Vrouwenvelder T. (2012) Hydra Ring Scientific Documentation, 1206006-004, Deltares / TNO

Silva W, Kuijper B, Huber N, Schüttrumpf H, Roßner S , Lorke S, (2009) Risikoanalyse für die grenzüberschreitenden Deichringe am Niederrhein (in German) Risicoanalyse grensoverschrijdende dijkringen Niederrhein (in Dutch)

Slager K. (2010) Watersnood (in Dutch), page 458459. Detailed description of the 1953 storm surge disaster for each flooded area)

Slomp R., Kolen B., Jaap van der Schaaf, van der, (2011) Renewed tools for crisis management of floods in the Netherlands Montpellier Georisques 7, January 25th and 26th 2011

Slomp, R.M. (2012) Flood Risk and Water Management in the Netherlands, A 2012 update, Rijkswaterstaat,

Slomp, R.M., J.P. de Waal, E.F.W. Ruijgh, T. Kroon and J.S.L.J. van Alphen, (2014). The Dutch Delta Model for Policy Analysis on Flood Risk Management In the Netherlands. 6th International Conference on Flood Management (ICFM6), September 2014, Sao Paulo, Brazil

Slomp, R.M. (2016), Implementing risk based flood defence standards, Rijkswaterstaat.

Slomp, R.M., Knoeff, H., Bottema, M, (2016) Probabilistic Flood Defence Assessment Tools, Lyon, 2016, Flood Risk Conference.

Sprokkereef, E (2010), Powerpoint presentation, WMCN, Rijkswaterstaat

Torfs, P.J.J.F., (1990), Stochastische hydrologie, (tutorial Catchment Hydrology in Dutch), department of Hydraulics and Hydrology Wageningen University.

TMO, TASKFORCE MANAGEMENT OVERSTROMINGEN (2009) Results of the Taskforce Flood Risk Management "Rapport van Bevindingen TMO" (in Dutch)

http://www.rijksoverheid.nl/documenten-enpublicaties/rapporten/

Unden, P.et al, 2002 HIRLAM-5 Scientific Documentation, December 2002, http://hirlam.org/

VenW, Ministry of Transport and Water Management (1996) "Wet op de Waterkering", Flood Defence act http://wetten.overheid.nl/BWBR0007801/geldigheidsdatu m_04-12-2009 (in Dutch)

VenW and BZK. Ministry of Transport and Water Management (VenW) and Ministry of Interior (BZK), Ministerie van Verkeer en Waterstaat (VenW), Directoraat-Generaal Water (DGW); Ministerie van 
Binnenlandse Zaken en Koninkrijksrelaties (2006) Syntheserapport onderzoeksprogramma Rampenbeheersingsstrategie overstromingen Rijn en Maas, Flood Disaster Risk Reduction Study, DGW, Vrijling, J.K. Bruinsma, (1980) J. Hydraulic Boundary Conditions. In: Proceedings on Hydraulic Aspects of Coastal Structures; developments in hydraulic engineering related to the design of the Oosterschelde storm surge barrier in the Netherlands. Editors: A. Paape, J. Stuip, W.A. Venis, Delft University Press 1980, pp. 109 - 133, ISBN 90-6275-0540.

Vrouwenvelder, A.C.W.M., Steenbergen, H.M.G.M., Slijkhuis, K.A.H., , (2001) Theoretical manual of PCRing, Part A: descriptions of failure modes (in Dutch), Nr. 98-CONR1430

de Waal, (1999) Achtergronden Hydraulische Belastingen Dijken IJsselmeergebied. Een ontwerpmethodiek, (in Dutch) RIZA, Rijkswaterstaat Lelystad, Deelrapport 9: Modellering dammen, voorlanden en golfoploop. RIZA rapport 99.046. J.P. de Waal.

Warmerdam, P.M.M. (1986) Afvoerhydrologie, Hydrology (tutorial Catchment Hydrology in Dutch), department of Hydraulics and Hydrology Wageningen University.

Westphal R, Hartman J. (1999), Achtergronden Hydraulische Belastingen Dijken IJsselmeergebied. Een ontwerpmethodiek, (in Dutch) RIZA, Rijkswaterstaat Lelystad, "Hydraulic loads in the IJsselake area, a design method"

Zijlema, M., (2007) SWAN, User Manual, SWAN Cycle III version 40.51, TU Delft,

Zon, van der N.,(2013) Quality document for the national digital terrain model Kwaliteitsdocument AHN2 